\title{
Experimental Study on the Performance and Microstructure of Cementitious Materials Made with Dune Sand
}

\author{
Chaohua Jiang, ${ }^{1,2}$ Xiaobin Zhou, ${ }^{1,2}$ Guilan Tao, ${ }^{1,2}$ and Da Chen ${ }^{1,2}$ \\ ${ }^{1}$ Jiangsu Key Laboratory of Coast Ocean Resources Development and Environment Security, Hohai University, Nanjing 210098, China \\ ${ }^{2}$ College of Harbour, Coastal and Offshore Engineering, Hohai University, Nanjing 210098, China
}

Correspondence should be addressed to Da Chen; chenda@hhu.edu.cn

Received 14 July 2016; Revised 18 September 2016; Accepted 21 September 2016

Academic Editor: Kestutis Baltakys

Copyright (C) 2016 Chaohua Jiang et al. This is an open access article distributed under the Creative Commons Attribution License, which permits unrestricted use, distribution, and reproduction in any medium, provided the original work is properly cited.

This paper presents the results of an investigation on the utilization of dune sand from waterway regulation engineering as the main raw materials to produce cementitious materials. The mechanical and durability properties of the cementitious materials were studied. Furthermore, a scanning electron microscope (SEM) and mercury intrusion porosimeter (MIP) were used to identify the microstructure of the specimens. The results show that the compressive and splitting tensile strength of cementitious materials can be improved due to the addition of ground granulated blast-furnace slag (GGBS) which mainly attributes to a better grain size distribution and pozzolanic effect compared to the specimen added cement alone. The specimen with the addition of suitable cement, GGBS, and gypsum shows low dry shrinkage and excellent abrasion resistance. Correspondingly the specimens present a lower porosity and total volume of pores at different curing ages. The SEM observation indicates that there are quite a lot of hydrate products such as calcium silicate hydrate gel in the matrix which verifies the formation of cementitious compounds. The results obtained suggest that there is potential in manufacturing cementitious material with dune sand in substitution of ordinary concrete to use in hydraulic engineering.

\section{Introduction}

There is an abundance of very fine natural sand known as dune sand mainly distributed in coastal rivers and desert areas $[1,2]$. It is quite difficult to applicate dune sand in civil engineering because of its features of poor gradation, low strength, looseness, ease of erosion, and the poor overall stability $[3,4]$. Furthermore, in some dredging and waterway regulation engineering such as bank protection and slope cutting, a considerable amount of dune sand has been generated. The disposal of this huge waste sand poses a serious problem in terms of land use and potential environmental pollution. Thus, it is important to find new uses to develop the necessary technology for new processes to address this waste and to take advantage of these processes to reduce the environmental impacts of engineering projects. Utilization of the dune sand to make cementitious materials and its application in civil engineering, such as substituting ordinary concrete to produce ballast block used in hydraulic engineering, can reduce land taking and avoid transportation and pollution of waste soil, which would create high economic and environmental benefits.

In order to meet the requirements of engineering construction using local resources and reducing the transportation costs, many research works have been conducted to use dune sand as a fine aggregate to make concrete, especially in desert regions [5-7]. The fineness modulus of dune sand is usually less than 1.5 or the average particle size is less than $0.25 \mathrm{~mm}$ which belongs to superfine sand [3]. The concrete with the dune sand as a fine aggregate is usually regarded as having low workability and low ductility, although it has certain economic advantages. Zhang et al. [8] used the Tenggeli and Maowusu dune sand as fine aggregate to produce concrete. The result showed that the sand/gravel ratio was controlled in the range of $28-32 \%$. The concrete with no additives showed poor workability and small slump. Al-Harthy et al. [9] investigated the performance of concrete made with Oman dune sand partially introduced (10-100\%) as fine aggregate. The results showed that the workability improved and the strength of the concrete decreased with the increase 
in dune sand replacement. Alhozaimy et al. [10] carried out the study on the properties of the high strength concrete using the dune sand under normal and autoclaved curing. Results showed that it was possible to use the dune sand as a 30\% partial cement replacement under autoclaved curing. Lou et al. [11] investigated the performance of concrete using dune sand from the Australian desert as fine aggregate. It was found that the compressive strength of the dune sand concrete was comparable to that of river sand concrete.

Furthermore, due to the scarcity of coarse aggregates and the availability of a large amount of dune sand in some regions, there has been a growing interest in the utilization of dune sand to make sand concrete or mortar [12-16]. Sand concrete is a fine concrete where coarse aggregate is replaced by sand and fine aggregate is replaced by filler material [17]. Bédérina et al. [15] investigated the sand concrete made with local dune sands. Results showed that the compressive strength of the dune sand concrete could reach 16.0 MPa when the cement content was $350 \mathrm{~kg} / \mathrm{m}^{3}$ and filler content was $200 \mathrm{~kg} / \mathrm{m}^{3}$. Bouziani et al. [14] dealt with the effect of dune sand on the properties of flowing sand concrete (FSC) mixed with different proportions of river and dune sand. The results showed that FSC had good fluidity and a better performance in terms of compressive strength at 28 days when dune sand content was about $10 \%$ by mass of total sand. Zhang et al. [8] tested the performance of mortar made with Tenggeli and Maowusu dune sand. The result indicated that desert sand could be used as a fine aggregate in mortar for general civil engineering.

The brief review shows that the current main application of dune sand is used as fine aggregate in concrete mixtures. The studies on the utilization of dune sand to make sand concrete or mortar have been carried out. However, the main attention of these researches was given to the mechanical properties of the cementitious materials and attempting to substitute ordinary concrete. Very few studies focus on the potential application of cementitious materials made with dune sand in hydraulic engineering. The information about the durability of this cementitious material such as dry shrinkage or abrasion resistance is very limited. The studies on the microstructure of the cementitious materials such as pore size distribution and porosity are also very limited. Therefore, more studies need to be carried out in these aspects.

This study aims to utilize dune sand as alternative sand for the preparation cementitious materials in substitution of ordinary concrete to use in hydraulic engineering. The present work focuses on the effect of the content of cement, ground granulated blast-furnace slag (GGBS), and gypsum on the performance of cementitious materials made with dune sand, such as compressive and splitting tensile strength, drying shrinkage, abrasion resistance, and microstructure. The main purposes are to (1) investigate the compressive and splitting tensile strengths of cementitious materials, (2) analyze the durability of cementitious material through drying shrinkage and abrasion resistance tests and evaluate their potential utilization in hydraulic engineering, and (3) verify the formation of cementitious compounds and analyses of
TABLE 1: Properties of OPC, GGBS, and dune sand.

\begin{tabular}{|c|c|c|c|}
\hline & \multicolumn{3}{|c|}{ Item } \\
\hline & Cement (OPC) & GGBS & Dune sand \\
\hline \multicolumn{4}{|l|}{ Chemical composition (wt\%) } \\
\hline $\mathrm{CaO}$ & 62.25 & 37.04 & 8.76 \\
\hline $\mathrm{SiO}_{2}$ & 19.28 & 32.90 & 65.63 \\
\hline $\mathrm{Al}_{2} \mathrm{O}_{3}$ & 6.77 & 15.36 & 12.63 \\
\hline $\mathrm{Fe}_{2} \mathrm{O}_{3}$ & 3.47 & 2.46 & 3.42 \\
\hline $\mathrm{MgO}$ & 2.68 & 10.18 & 4.52 \\
\hline $\mathrm{Na}_{2} \mathrm{O}$ & 1.18 & 1.12 & 1.83 \\
\hline $\mathrm{K}_{2} \mathrm{O}$ & 0.36 & 0.15 & 1.87 \\
\hline $\mathrm{SO}_{3}$ & 1.64 & 0.08 & 0.06 \\
\hline $\mathrm{TiO}_{2}$ & - & - & 0.58 \\
\hline Loss on ignition & - & 0.38 & - \\
\hline \multicolumn{4}{|l|}{ Physical properties } \\
\hline Specific gravity $\left(\mathrm{g} / \mathrm{cm}^{3}\right)$ & 3.10 & 2.84 & - \\
\hline Specific surface $\left(\mathrm{m}^{2} / \mathrm{kg}\right)$ & 385 & 425 & - \\
\hline Fineness modulus & - & - & 0.85 \\
\hline Initial setting time (min) & 90 & - & - \\
\hline Final setting time (min) & 185 & - & - \\
\hline \multicolumn{4}{|l|}{$\begin{array}{l}\text { Mineralogical composition } \\
\text { (wt\%) }\end{array}$} \\
\hline $\mathrm{C}_{3} \mathrm{~S}$ & 51.69 & - & - \\
\hline $\mathrm{C}_{2} \mathrm{~S}$ & 16.35 & - & - \\
\hline $\mathrm{C}_{3} \mathrm{~A}$ & 12.07 & - & - \\
\hline $\mathrm{C}_{4} \mathrm{AF}$ & 10.54 & - & - \\
\hline
\end{tabular}

pore size distribution of cementitious materials by SEM and MIP techniques, respectively.

\section{Materials and Methods}

\subsection{Materials}

2.1.1. Cement. In this study, Ordinary Portland Cement was obtained from the Conch Cement Pty. Ltd., China. The chemical compositions determined according to BS EN 1971:2011 and the properties of OPC are presented in Table 1.

2.1.2. Mineral Admixture. In this study, GGBS supplied by a construction company located in the Nanjing of China was used as mineral admixture. GGBS used comply with BS 6699:1992. The chemical compositions and physical properties of GGBS are illustrated in Table 1.

2.1.3. Gypsum. The gypsum used was industrial products provided by JiuYi Pty. Ltd. in Shanghai, China. The content of $\mathrm{Ca}_{2} \mathrm{SO}_{4} \cdot 2 \mathrm{H}_{2} \mathrm{O}$ in the gypsum is about $85.0 \%$.

2.1.4. Admixture. A polycarboxylate high range water reducing superplasticizer (SP) in liquid conforming to the GB80762008 was used. The product meets GB8076-2008 standard. 


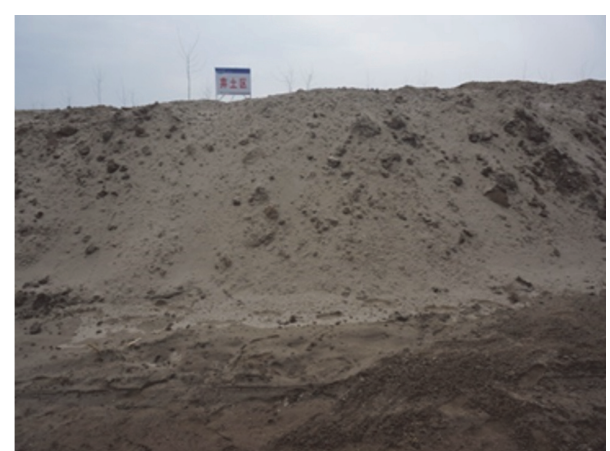

Figure 1: The studied dune sand at the revetment of Yangtze River.

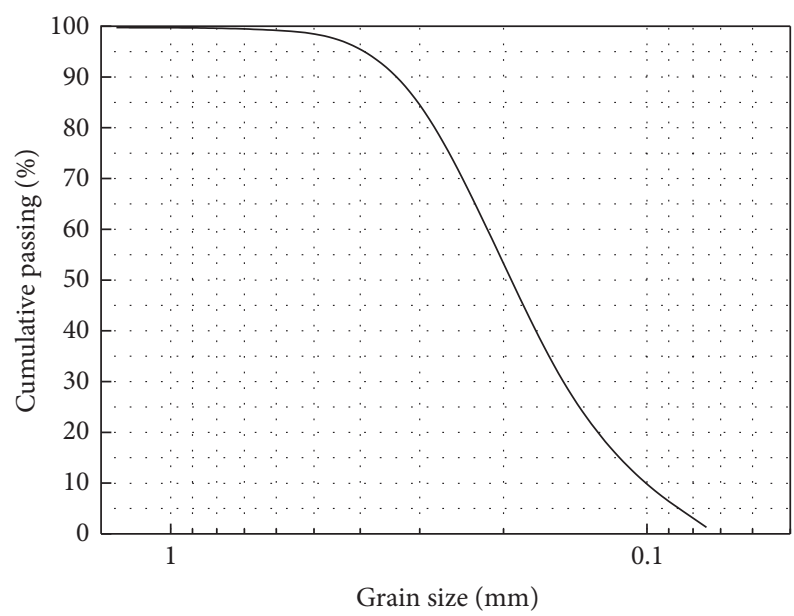

FIGURE 2: Grain size distribution of the studies dune sands.

The active ingredients of SP are more than $97 \%$ and with 7-8 $\mathrm{pH}$ value.

2.1.5. Fine Aggregate. The dune sand sample shown in Figure 1, which was collected from a typical bank slope of the Yangtze River in China, was used as fine aggregate. The grain size distribution of the dune sand was determined using the dry sieve analysis method and presented in Figure 2 . The dune sand exhibits a uniform structure with about $90 \%$ grain sizes ranging between 0.08 and $0.3 \mathrm{~mm}$. The chemical composition of the sand is presented in Table 1 . It can be seen that the main compositions of dune sand are $\mathrm{SiO}_{2}, \mathrm{Al}_{2} \mathrm{O}_{3}$, and $\mathrm{CaO}$. There are no toxic ingredients and heavy metals such as $\mathrm{Cd}, \mathrm{Cr}$, and $\mathrm{Zn}$ in the dune sand. The mineralogical composition of the dune sand was determined by X-ray diffraction (XRD) analysis tested by UltimaIV made in Japan. The main minerals are $3 \%$ quartz, $18 \%$ feldspar, $17 \%$ amphibole, $13 \%$ chlorite, $10 \%$ water mica, $5 \%$ vermiculite, and $3 \%$ dolomite.

2.2. Mix Proportions. In this study, equivalent substitution method was used to design mixing proportions. For all mixtures, SP was added in proportion of $0.5 \%$ by weight of binder. The mixing proportions of samples are given in Table 2 .
2.3. Preparation and Curing Conditions of Samples. The dune sand, GGBS, cement, and gypsum were initially mixed dry in a mixer for about 2 minutes until they were homogenous throughout. Then, the entire amount of mixing water with the SP was added and the mixing process lasted for another 3 minutes, leading to a total mixing period of 5 minutes. Finally, the fresh mixed materials were cast in the molds and vibrated by a mechanical vibrating table for $2-3 \mathrm{~min}$. After that, the specimens produced were cured in air at $20 \pm 2^{\circ} \mathrm{C}$ in molds covered by a polyethylene film to prevent moisture loss. After $24 \mathrm{~h}$, the samples were removed from the molds and transferred to a standard condition with $T=20 \pm 2^{\circ} \mathrm{C}$ and $\mathrm{RH}=95 \pm 5 \%$ until the testing age. In this study, every test result consists of the average of three replicate tests except one sample for the pore structure test.

\subsection{Testing Methods}

2.4.1. The Fresh Properties Test. The workability of the fresh cementitious materials was indicated by the slump flow (by flow table) of the material measured by a slump test according to EN 1015-3. The air content of the fresh cementitious material was tested according to Chinese National Standard GJ/ T70-2009 method and the density of the freshly cementitious material was determined using ASTM C138/C138 M-14.

2.4.2. Compressive and Splitting Tensile Strength. The compressive and splitting tensile strength of the cube specimens with side lengths of $100 \mathrm{~mm}$ were tested according to GB/T 50081-2002, at the curing periods of 7, 28, and 90 days, respectively.

2.4.3. Drying Shrinkage. The drying shrinkage test of mortar was conducted on three $40 \mathrm{~mm} \times 40 \mathrm{~mm} \times 160 \mathrm{~mm}$ prismatic specimens according to GB/T 50081-2002 method. The initial lengths of the mortar bars were measured after curing in the laboratory for $24 \mathrm{~h}$. Then, the mortar samples were conveyed to a drying chamber with a temperature of $20-25^{\circ} \mathrm{C}$ and a relative humidity of $50-55 \%$ until further measurements at $1,3,7,14,21,28,42$, and 56 days.

2.4.4. Abrasion Resistance. The abrasion resistance of the mortar specimens was tested according to ASTM C 1138/97 (an underwater method). Three $\varphi 300 \mathrm{~mm} \times 100 \mathrm{~mm}$ cylinder specimens were used for the abrasion resistance test. The specimens were abraded by underwater steel balls for a period of 72 hours. The weight loss and the abrasion resistance strength of the specimens were used to evaluate the abrasion resistance properties of specimens.

2.4.5. Microstructure Analysis. SEM analysis was carried out on $\mathrm{C} 4 \mathrm{mix}$, cured for 7 and 28 days separately, which were sampled from cube samples dried in an oven at $40^{\circ} \mathrm{C}$. The microstructure of the sample was tested by JSM-5900 SEM made by JEOL in Japan. And the pore size distribution and the porosity of the specimen were tested by PoreMaster GT60 MIP produced by Quantachrome, USA. 
TABLE 2: Mixing proportions of samples by weight and the mix code.

\begin{tabular}{lccccc}
\hline Code & Sand $\left(\mathrm{kg} / \mathrm{m}^{3}\right)$ & Cement $\left(\mathrm{kg} / \mathrm{m}^{3}\right)$ & GGBS $\left(\mathrm{kg} / \mathrm{m}^{3}\right)$ & Gypsum $\left(\mathrm{kg} / \mathrm{m}^{3}\right)$ & - \\
\hline C1 & 1415.0 & 450.0 & - & - & - \\
C2 & 1408.8 & 365.0 & 85.0 & - & 225.0 \\
C3 & 1402.6 & 280.0 & 170.0 & 45.0 & 225.0 \\
C4 & 1397.7 & 235.0 & 170.0 & 90.0 & 225.0 \\
C5 & 1392.8 & 190.0 & 170.0 & & 225.0 \\
\hline
\end{tabular}

\section{Results and Discussion}

3.1. Fresh Properties. The test results relevant to the fresh properties of cementitious materials such as the slump flow, density, and air content are presented in Table 3.

From Table 3, it can be seen that the slump flow diameter of mix of C2, C3, C4, and C5 is $136 \mathrm{~mm}, 143 \mathrm{~mm}, 142 \mathrm{~mm}$, and $140 \mathrm{~mm}$, an increasing of $3.03 \%, 8.33 \%, 7.57 \%$, and $6.06 \%$ in comparison to the slump flow diameter of the $\mathrm{C} 1 \mathrm{mix}$ with cement addition alone. The incorporation of GGBS into the materials increases the slump flow diameter of the cementitious materials which mainly contributes to a better particle size distribution. Fine GGBS particles fill wide pores among cement particles and reduce water requirement [18].

As noticed, air content for $\mathrm{C} 2, \mathrm{C} 3, \mathrm{C} 4$, and $\mathrm{C} 5 \mathrm{mix}$ is $13.7 \%, 13.2 \%, 12.3 \%$, and $12.6 \%$, which decreased to $5.5 \%$, $8.9 \%, 15.2 \%$, and $13.1 \%$ in comparison to the air content of the $\mathrm{Cl}$ mix with cement addition alone. The $\mathrm{C} 1 \mathrm{mix}$ with cement addition alone has the lowest density. When the replacement amount of GGBS increases, the density of cementitious material increases significantly. The density of specimens increases from $2.08 \mathrm{~g} / \mathrm{m}^{3}$ to $2.12 \mathrm{~g} / \mathrm{m}^{3}$ when the replacement amount of GGBS varies from $85.0 \mathrm{~kg} / \mathrm{m}^{3}$ to $170.0 \mathrm{~kg} / \mathrm{m}^{3}$. The incorporation of GGBS contributes to a better grain size distributions and compactness which resulted in a higher density of specimens.

3.2. Compressive Strength Development. Figure 3 illustrates the strength development of the mixes after 7, 28, and 90 days of curing. It can be seen that the compressive strength of all the mixes increases with the curing time. The presence of GGBS in the cementitious materials has a significant effect on the improvement of compressive strength. When GGBS replacement amounts are $85.0 \mathrm{~kg} / \mathrm{m}^{3}$ and $170.0 \mathrm{~kg} / \mathrm{m}^{3}$, the compressive strength of specimen at 28 days increases by $6.42 \%$ and $13.58 \%$, respectively, more than that of addition of cement alone.

The improvement in compressive strength with the addition of GGBS is mainly related to a better particle size distribution which results in a higher compactness and consequently higher strength. In addition, the pozzolanic reaction of GGBS also contributes to the strength development especially for late ages, where the silica and alumina react with calcium hydroxide $\mathrm{Ca}(\mathrm{OH})_{2}$ to produce calcium silicate hydrates $(\mathrm{CSH})$ and calcium aluminium silicate hydrates (CASH), which play a crucial role in strength development. The formation of cementitious compounds $\mathrm{CSH}$ can be effectively proved by the SEM results in the later section.
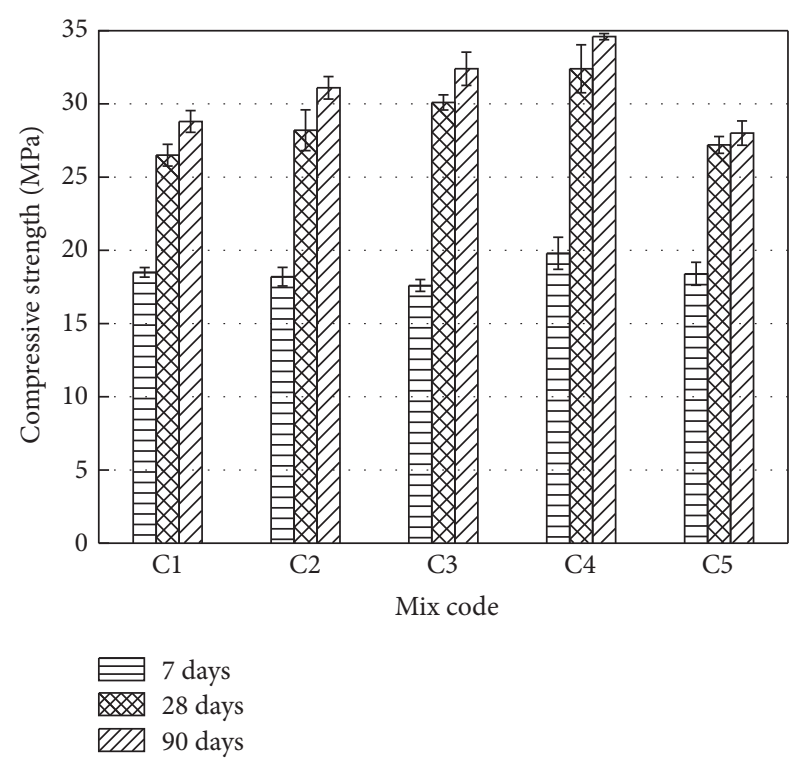

FIGURE 3: Development of compressive strength of designed mixes.

For the $\mathrm{C} 4 \mathrm{mix}$, when the replacement amount of gypsum is $45.0 \mathrm{~kg} / \mathrm{m}^{3}$, the compressive strengths at 7,28 , and 90 days increase by $12.52 \%, 7.64 \%$, and $6.79 \%$, respectively, compared to the C3 mix without the addition of gypsum. However, if the replacement amount of gypsum in the mix varies from $45.0 \mathrm{~kg} / \mathrm{m}^{3}$ to $90.0 \mathrm{~kg} / \mathrm{m}^{3}$, the compressive strength decreases by $7.07 \%, 16.05 \%$, and $19.05 \%$ at the curing periods of 7,28 , and 90 days, respectively. The addition of appropriate gypsum can promote the secondary hydration or pozzolanic reaction of GGBS which contributes to the early strength development of cementitious materials $[19,20]$, while too much gypsum could produce large amounts of ettringite which will cause expanded internal stress and have a negative effect on the strength of the material.

3.3. Splitting Tensile Strength Development. The results of the splitting tensile strength of specimens at the curing periods of 7,28 , and 90 days are described in Figure 4. It can be seen that the splitting tensile strengths of all the mixes increase with the curing time. The addition of GGBS increases strength of mixture effectively which contributes similarly to a better particle size distribution and pozzolanic reaction. When the replacement amount of GGBS is $85 \mathrm{~kg} / \mathrm{m}^{3}$ and $170.0 \mathrm{~kg} / \mathrm{m}^{3}$, the splitting tensile strengths of specimen increase by $5.21 \%$ and $17.06 \%$, respectively, at 28 days compared with $\mathrm{C} 1 \mathrm{mix}$ addition of cement alone. 
TABLE 3: Fresh properties of cementitious materials.

\begin{tabular}{|c|c|c|c|c|c|c|}
\hline \multirow{2}{*}{ Mixture number } & \multicolumn{2}{|c|}{ Slump flow diameter $(\mathrm{mm})$} & \multicolumn{2}{|c|}{ Content of air (\%) } & \multicolumn{2}{|c|}{ Density $\left(\mathrm{g} / \mathrm{cm}^{3}\right)$} \\
\hline & Average & Standard deviation & Average & Standard deviation & Average & Standard deviation \\
\hline $\mathrm{C} 1$ & 132 & 3.56 & 14.5 & 0.24 & 2.05 & 0.024 \\
\hline $\mathrm{C} 2$ & 136 & 2.16 & 13.7 & 0.36 & 2.08 & 0.029 \\
\hline $\mathrm{C} 3$ & 143 & 3.27 & 13.2 & 0.14 & 2.12 & 0.014 \\
\hline $\mathrm{C} 4$ & 142 & 2.94 & 12.3 & 0.29 & 2.10 & 0.016 \\
\hline C5 & 140 & 2.16 & 12.6 & 0.28 & 2.07 & 0.022 \\
\hline
\end{tabular}

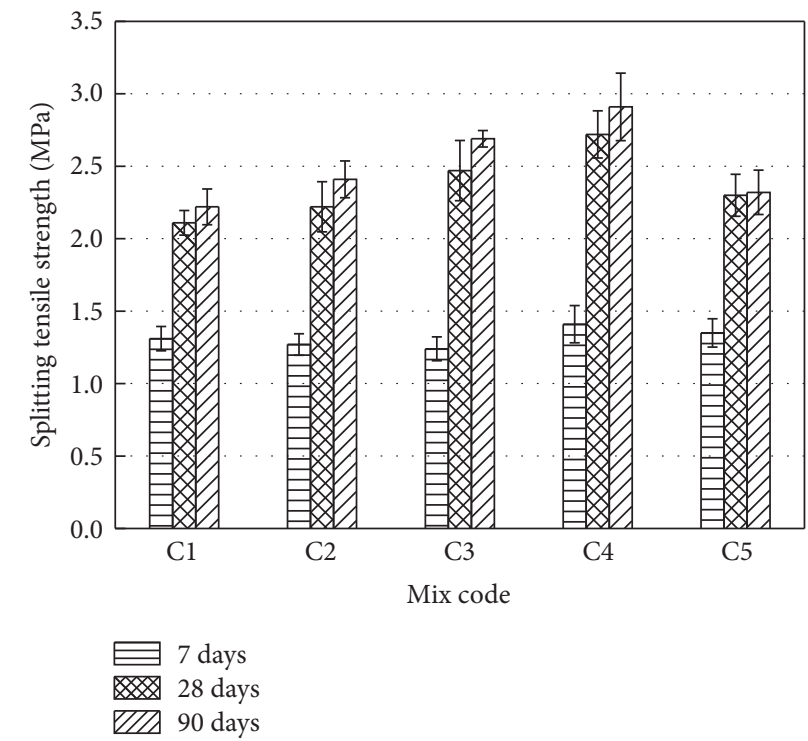

FIGURE 4: Development of splitting tensile strength of designed mixes.

For the $\mathrm{C} 4 \mathrm{mix}$, the splitting tensile strengths at the curing periods of 7,28 , and 90 days increase by $5.22 \%, 10.12 \%$, and $8.17 \%$, respectively, compared to the C3 mix without gypsum added, due to the addition of $45 \mathrm{~kg} / \mathrm{m}^{3}$ gypsum. Similarly, when the replacement amount of gypsum varies from $45 \mathrm{~kg} / \mathrm{m}^{3}$ to $90 \mathrm{~kg} / \mathrm{m}^{3}$, the splitting tensile strengths at the curing periods of 7,28 , and 90 days decrease by $13.71 \%$, $15.44 \%$, and $20.32 \%$, respectively.

3.4. Drying Shrinkage Development. Benaissa [21] found that the shrinkage property of cementitious material made with superfine sand was much higher than that of conventional concrete. Therefore, it is essential and meaningful to carry out the shrinkage properties test of the cementitious material made with dune sand. The dry shrinkage test results are described in Figure 5. It can be seen that the drying shrinkage of all specimens increased immediately at an early age and tended to stabilize with increases in curing time. It was found that the drying shrinkage of all blended cementitious material containing GGBS and gypsum materials was lower than that of adding cement alone. When the replacement amount of GGBS is $85 \mathrm{~kg} / \mathrm{m}^{3}$ and $170 \mathrm{~kg} / \mathrm{m}^{3}$, the dry shrinkage decreases by $7.58 \%$ and $12.87 \%$, respectively, compared with $\mathrm{C} 1 \mathrm{mix}$ addition of cement alone at 1 day. A swelling effect occurred

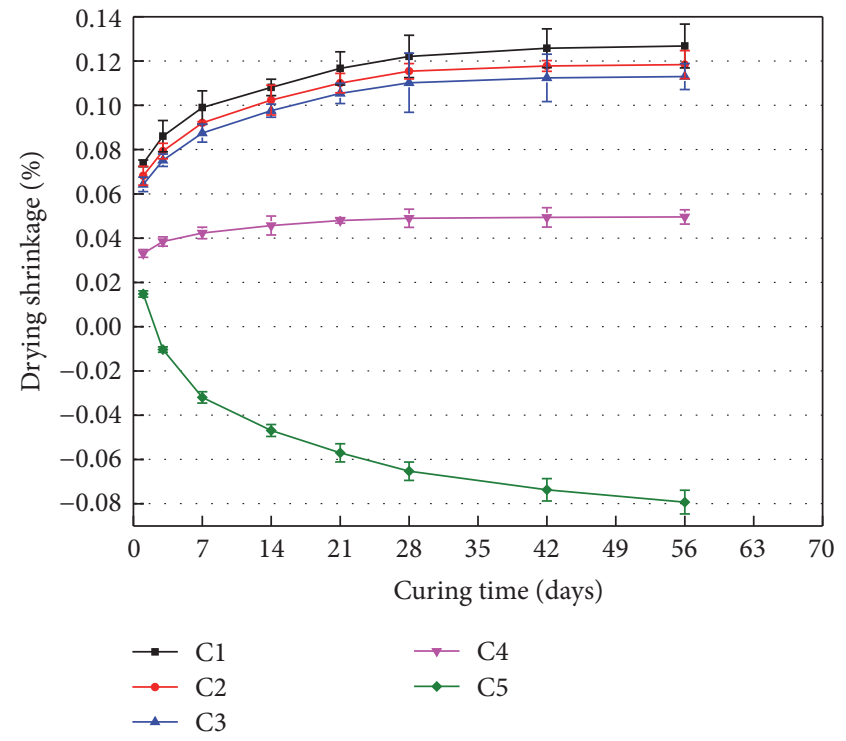

FIGURE 5: Development of dry shrinkage of designed mixes.

with the addition of gypsum resulting in a significant reduction in the drying shrinkage of the $\mathrm{C} 4 \mathrm{mix}$, even an obvious expansion for C5 mix. When replacement amount of GGBS and gypsum is $170 \mathrm{~kg} / \mathrm{m}^{3}$ and $45 \mathrm{~kg} / \mathrm{m}^{3}$, the dry shrinkage decreases by $56.15 \%$ and $51.22 \%$ compared with $\mathrm{C} 1 \mathrm{mix}$ at 1 day and 28 days, respectively.

Drying shrinkage is a paste property, a volumetric contraction of hardened cementitious material. Results from SEM combined with MIP in later sections reveal that GGBS particles present a pore refining effect on cementitious material specimens, which results in much denser microstructure and lower shrinkage value.

3.5. Abrasion Resistance. Figure 6 shows the abrasion resistance test results, indicating that the addition of GGBS and gypsum improves the abrasion resistance of specimens. When the replacement amount of GGBS and gypsum is $170 \mathrm{~kg} / \mathrm{m}^{3}$ and $45 \mathrm{~kg} / \mathrm{m}^{3}$, the weight loss and abrasion resistance strength of C4 mix are $6.65 \%$ and $24.01 \mathrm{~h} \cdot \mathrm{m}^{2} / \mathrm{kg}$, respectively. Compared with the $\mathrm{C} 1 \mathrm{mix}$ addition of cement alone, weight loss of $\mathrm{C} 4 \mathrm{mix}$ deceases by $31.23 \%$ and its abrasion resistance strength increases by $45.43 \%$. Sadegzadeh et al. [22] have pointed out that abrasion resistance was determined by the pore structure. As mentioned above, the addition of 


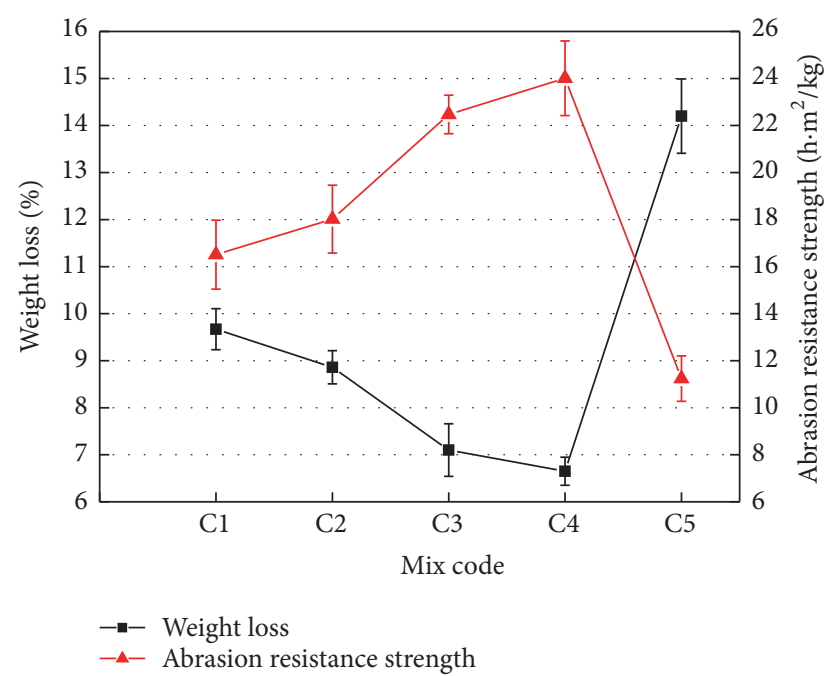

FiguRE 6: Abrasion resistance test results of the cementitious materials.

GGBS particles presented a pore refining effect on cementitious material specimens by improving particle size distribution and pozzolanic reaction thereby enhancing abrasion resistance properties. The test by Galvão et al. [23] verified that the cementitious materials reinforced with polymer showed about $5.04-7.46 \%$ mass loss after the same abrasionerosion test. When this material was utilized to repair dam surfaces, there were no edges or deleterious actions (erosionabrasion) caused by the environment or the water flow in the flowing periods of the barrage's reservoir occurring after one year. This indicated that the $\mathrm{C} 4 \mathrm{mix}$ with a weight loss of $6.65 \%$ presents excellent abrasion resistance and can be used in hydraulic engineering.

3.6. Microstructure Analysis. The SEM technique was used in this study to explain the hydrate mechanism of cementitious materials made with dune sand. Figure 7 shows the SEM images of the microstructure of the $\mathrm{C} 4 \mathrm{mix}$ at the curing age of 7 and 28 days. Figures $7(\mathrm{a})$ and $7(\mathrm{c})$ indicate that the microstructure of cementitious material is quite dense especially at 28 days which can be explained by the substantial reduction of void areas as a result of hydration reactions. Various hydrate products such as $\mathrm{CSH}$ gel, $\mathrm{Ca}(\mathrm{OH})_{2}$, and ettringite at matrix revealed the presence of various cementation compounds in the dune sand matrix and verified the formation of cementitious compounds. These hydrated compounds have a significant effect on strength development. At 7 days, tabular $\mathrm{Ca}(\mathrm{OH})_{2}$, cotton-shaped C-S-H gels, and needle ettringite intertwined and overlapped each other to generate a stable structure of paste. At 28 days, the pores are filled with the needle bar shaped ettringite and C-S-H gel which make up the structure defects gradually. Structures become denser compared with the specimens at early age, which shows that the strength of the specimen increases.

3.7. Pore Size Distribution and Porosity. In this section, the pore structures of cementitious materials with different contents of GGBS and gypsum at curing periods of 7 and 28 days are discussed and shown in Table 4. Three characteristic ranges of pore sizes are identified: $<10 \mathrm{~nm}, 10-100 \mathrm{~nm}$, and $>100 \mathrm{~nm}$. According to the study by Wu and Lian [24], pores with sizes smaller than $10 \mathrm{~nm}$ are harmless pores, between $10 \mathrm{~nm}$ and $100 \mathrm{~nm}$ are minor harmful pores, and bigger than $100 \mathrm{~nm}$ are harmful pores.

It can be seen that both the total pore volume and porosity of specimens decrease with curing time. The porosity of the C4 mix with $170 \mathrm{~kg} / \mathrm{m}^{3} \mathrm{GGBS}$ and $45 \mathrm{~kg} / \mathrm{m}^{3}$ gypsum addition decreases from $0.0878 \mathrm{~cm}^{3} / \mathrm{cm}^{3}$ at 7 days to $0.0657 \mathrm{~cm}^{3} / \mathrm{cm}^{3}$ at 28 days. And the $\mathrm{C} 4 \mathrm{mix}$ presents the lowest total pore volume and porosity. Compared with the $\mathrm{C} 1 \mathrm{mix}$ addition of cement alone, the porosity of C4 mix decreased by $19.58 \%$ at 28 days.

Furthermore, the pore size distribution of cementitious materials also changes. On the one hand, the pores become finer with the addition of GGBS and gypsum. Compared with $\mathrm{C} 1 \mathrm{mix}$, the mix with the GGBS addition has more harmless pores and minor harmful pores. For example, the harmless pore $(<10 \mathrm{~nm})$ of the C4 mix is $15.64 \%$, while the harmless pore of $\mathrm{C} 1 \mathrm{mix}$ addition cement alone is $11.23 \%$ at 28 days. This result is in agreement with the results of compressive strength, which provides evidence that the presence of GGBS improves the strength of cementitious materials. Furthermore, Uchikawa et al. [25] have shown that adding mineral powder in concrete reduces the size of hydration products, inhibits the deposit of $\mathrm{Ca}(\mathrm{OH})_{2}$ by virtue of their filling role, and, consequently, decreases pore size.

\section{Conclusions}

The experimental study on the performance evaluation and microstructure of cementitious materials made with waste dune sand from the waterway regulation engineering reveals the following conclusions:

(1) The compressive and splitting tensile strength reach 32.4 MPa and 2.72 MPa, respectively, at 28 days when the replacement amount of GGBS and gypsum is $170 \mathrm{~kg} / \mathrm{m}^{3}$ and $45 \mathrm{~kg} / \mathrm{m}^{3}$, respectively. The compressive and splitting tensile strength of cementitious materials can be improved due to addition of GGBS, which mainly attributes to a better grain size distribution and pozzolanic effect compared to the specimen adding cement alone.

(2) The specimen addition of appropriate cement, GGBS, and gypsum shows low dry shrinkage and excellent abrasion resistance properties. When the replacement amount of GGBS and gypsum is $170 \mathrm{~kg} / \mathrm{m}^{3}$ and $45 \mathrm{~kg} / \mathrm{m}^{3}$, the weight loss and abrasion resistance strength of specimens are $6.65 \%$ and $24.01 \mathrm{~h} \cdot \mathrm{m}^{2} / \mathrm{kg}$, respectively, which presents an excellent abrasion resistance.

(3) SEM observation indicates that there are quite a lot of hydrate products such as CSH gel and ettringite in the matrix which verifies the formation of cementitious compounds. The MIP results indicate that the cementitious material addition of the GGBS and gypsum 


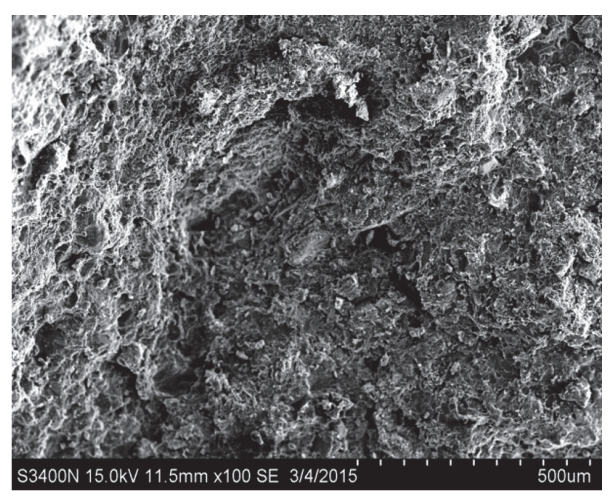

(a)

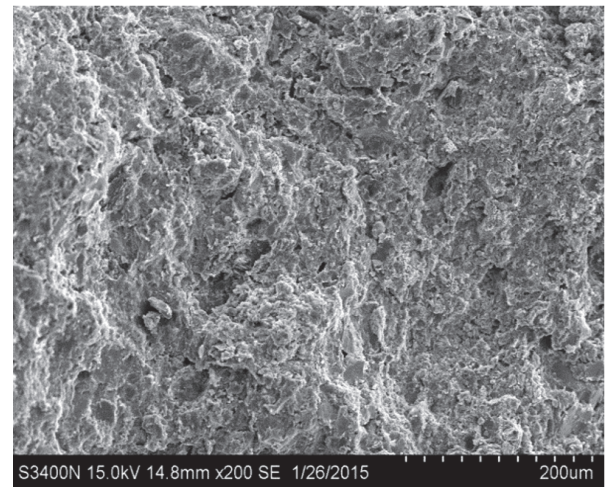

(c)

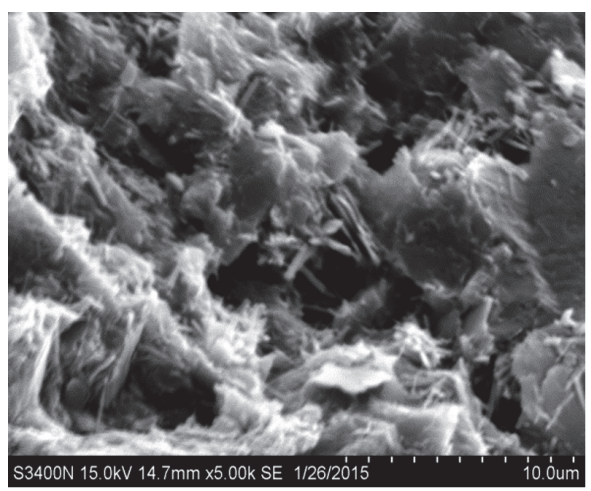

(b)

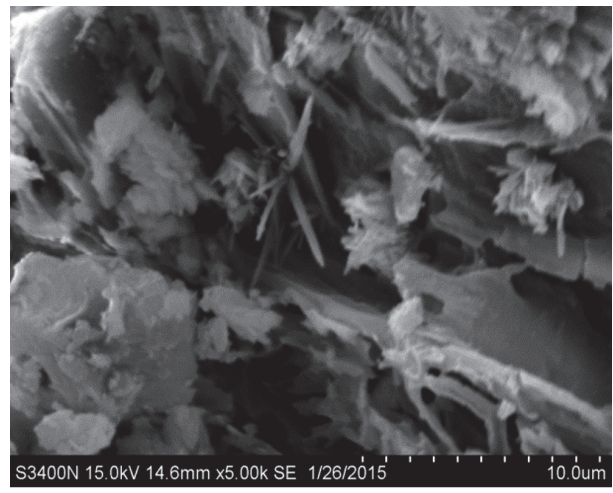

(d)

FIGURE 7: Scanning micrographs of cementitious materials: (a) 7 days $\times 100$, (b) 7 days $\times 5000$, (c) 28 days $\times 200$, and (d) 28 days $\times 5000$.

TABLE 4: Pore size distribution of the cementitious materials.

\begin{tabular}{|c|c|c|c|c|c|c|c|c|c|}
\hline \multirow{3}{*}{ Mixture number } & \multirow{3}{*}{ Age (d) } & \multicolumn{6}{|c|}{ Pore size distribution } & \multirow{3}{*}{$\begin{array}{l}\text { Total pore volume } \\
\qquad \mathrm{cm}^{3} / \mathrm{g}\end{array}$} & \multirow{3}{*}{$\begin{array}{l}\text { Total porosity } \\
\mathrm{cm}^{3} / \mathrm{cm}^{3}\end{array}$} \\
\hline & & \multicolumn{2}{|c|}{$<10 \mathrm{~nm}$} & \multicolumn{2}{|c|}{$10 \sim 100 \mathrm{~nm}$} & \multicolumn{2}{|c|}{$>100 \mathrm{~nm}$} & & \\
\hline & & $\mathrm{cm}^{3} / \mathrm{cm}^{3}$ & $\%$ & $\mathrm{~cm}^{3} / \mathrm{cm}^{3}$ & $\%$ & $\mathrm{~cm}^{3} / \mathrm{cm}^{3}$ & $\%$ & & \\
\hline $\mathrm{Cl}$ & 7 & 0.0039 & 7.97 & 0.0118 & 24.12 & 0.0334 & 67.91 & 0.0492 & 0.1018 \\
\hline $\mathrm{C} 3$ & 7 & 0.0042 & 9.23 & 0.0120 & 26.22 & 0.0290 & 64.55 & 0.0459 & 0.0950 \\
\hline $\mathrm{C} 4$ & 7 & 0.0053 & 12.38 & 0.0121 & 28.62 & 0.0249 & 59.00 & 0.0422 & 0.0878 \\
\hline $\mathrm{C} 1$ & 28 & 0.0044 & 11.23 & 0.0118 & 30.01 & 0.0228 & 58.12 & 0.0393 & 0.0817 \\
\hline $\mathrm{C} 3$ & 28 & 0.0048 & 13.21 & 0.0114 & 31.65 & 0.0203 & 56.14 & 0.0362 & 0.0753 \\
\hline $\mathrm{C} 4$ & 28 & 0.0049 & 15.64 & 0.0104 & 32.98 & 0.0167 & 52.78 & 0.0316 & 0.0657 \\
\hline
\end{tabular}

presents lower porosity and total volume of pores at different curing ages compared with the specimen addition of cement alone.

The results obtained suggest that there is potential in manufacturing cementitious material with waste dune sand in substitution of ordinary concrete to use in hydraulic engineering. In addition, the effective use of waste dune sand contributes to the development of a sustainable society by reducing the huge quantity of solid waste and establishing a sound environment.

\section{Competing Interests}

The authors declare that there is no conflict of interests regarding the publication of this paper.

\section{Acknowledgments}

The work described in this paper was supported by the Natural Science Foundation of China (no. 51409088), the Natural Science Foundation of Jiangsu Province (no. BK20151496), and the Fundamental Research Funds for the Central Universities (no. 2014B06414).

\section{References}

[1] A. Belferra, A. Kriker, S. Abboudi, and S. T. Bi, "Effect of granulometric correction of dune sand and pneumatic waste metal fibers on shrinkage of concrete in arid climates," Journal of Cleaner Production, vol. 112, pp. 3048-3056, 2016.

[2] O. A. Alawad, A. Alhozaimy, M. S. Jaafar, A. Al-Negheimish, and F. N. A. Aziz, "Microstructure analyses of autoclaved 
ground dune sand-Portland cement paste," Construction and Building Materials, vol. 65, pp. 14-19, 2014.

[3] W.-H. Wang, L.-H. Han, W. Li, and Y.-H. Jia, "Behavior of concrete-filled steel tubular stub columns and beams using dune sand as part of fine aggregate," Construction and Building Materials, vol. 51, pp. 352-363, 2014.

[4] C. A. Anagnostopoulos, "Strength properties of an epoxy resin and cement-stabilized silty clay soil," Applied Clay Science, vol. 114, pp. 517-529, 2015.

[5] B. H. Jin, J. X. Song, and H. F. Liu, "Engineering characteristics of concrete made of desert sand from Maowusu Sandy Land," Applied Mechanics and Materials, vol. 174-177, pp. 604-607, 2012.

[6] S. El Euch Khay, J. Neji, and A. Loulizi, "Compacted dune sand concrete for pavement applications," Proceedings of Institution of Civil Engineers: Construction Materials, vol. 164, no. 2, pp. 8793, 2011.

[7] E.-S. S. A. Seif, "Assessing the engineering properties of concrete made with fine dune sands: an experimental study," Arabian Journal of Geosciences, vol. 6, no. 3, pp. 857-863, 2013.

[8] G. X. Zhang, J. X. Song, J. S. Yang, and X. Y. Liu, "Performance of mortar and concrete made with a fine aggregate of desert sand," Building and Environment, vol. 41, no. 11, pp. 1478-1481, 2006.

[9] A. S. Al-Harthy, M. A. Halim, R. Taha, and K. S. Al-Jabri, “The properties of concrete made with fine dune sand," Construction and Building Materials, vol. 21, no. 8, pp. 1803-1808, 2007.

[10] A. Alhozaimy, M. S. Jaafar, A. Al-Negheimish et al., "Properties of high strength concrete using white and dune sands under normal and autoclaved curing," Construction and Building Materials, vol. 27, no. 1, pp. 218-222, 2012.

[11] F. J. Luo, L. He, Z. Pan, W. H. Duan, X. L. Zhao, and F. Collins, "Effect of very fine particles on workability and strength of concrete made with dune sand," Construction and Building Materials, vol. 47, pp. 131-137, 2013.

[12] A. Benaissa, A. Kamen, K. Chouicha, and S. Malab, "Panneau 3D aubéton de sable," Materials and Structures, vol. 41, no. 8, pp. 1377-1391, 2008.

[13] S. Gérômey, Evaluation des Paramètres d'Obtention de la Qualité des Bétons Projetés Utilisés dans des Soutènements Provisoires, des Revêtements Définitifs et des Renforcements d'Ouvrages, Institut National des Sciences Appliquées de Lyon, Lyon, France, 2003.

[14] T. Bouziani, M. Bederina, and M. Hadjoudja, "Effect of dune sand on the properties of flowing sand-concrete (FSC)," International Journal of Concrete Structures and Materials, vol. 6, no. 1, pp. 59-64, 2012.

[15] M. Bédérina, M. M. Khenfer, R. M. Dheilly, and M. Quéneudec, "Reuse of local sand: effect of limestone filler proportion on the rheological and mechanical properties of different sand concretes," Cement and Concrete Research, vol. 35, no. 6, pp. 11721179, 2005.

[16] S. El Euch Khay, J. Neji, and A. Loulizi, "Shrinkage properties of compacted sand concrete used in pavements," Construction and Building Materials, vol. 24, no. 9, pp. 1790-1795, 2010.

[17] M. Boutouil, Traitement des vases dedragage par stabilisation/ solidification a base de ciment et additifs [Ph.D. thesis], Université du Havre, FrLe Havre, France, 1998.

[18] G. İ. Sezer, "Compressive strength and sulfate resistance of limestone and/or silica fume mortars," Construction and Building Materials, vol. 26, no. 1, pp. 613-618, 2012.
[19] C. S. Poon, S. C. Kou, L. Lam, and Z. S. Lin, "Activation of fly ash/cement systems using calcium sulfate anhydrite $\left(\mathrm{CaSO}_{4}\right)$," Cement and Concrete Research, vol. 31, no. 6, pp. 873-881, 2001.

[20] M. Gesoglu, E. Güneyisi, A. H. Nahhab, and H. Yazıcı, “The effect of aggregates with high gypsum content on the performance of ultra-high strength concretes and Portland cement mortars," Construction and Building Materials, vol. 110, pp. 346354, 2016.

[21] A. Benaissa, Déformation différées d'un béton de sable [Ph.D. thesis], University of Bordeaux, Bordeaux, France, 1992.

[22] M. Sadegzadeh, C. L. Page, and R. J. Kettle, "Surface microstructure and abrasion resistance of concrete," Cement and Concrete Research, vol. 17, no. 4, pp. 581-590, 1987.

[23] J. C. A. Galvão, K. F. Portella, A. Joukoski, R. Mendes, and E. S. Ferreira, "Use of waste polymers in concrete for repair of dam hydraulic surfaces," Construction and Building Materials, vol. 25, no. 2, pp. 1049-1055, 2011.

[24] Z. W. Wu and H. Z. Lian, High Performance Concrete, Railway Press of China, Beijing, China, 1999.

[25] H. Uchikawa, S. Hanehara, and H. Hirao, "Influence of microstucture on the physical properties of concentrate prepared by substituting mineral powder for part of fine aggregate," Cement and Concrete Research, vol. 26, no. 1, pp. 101-111, 1996. 

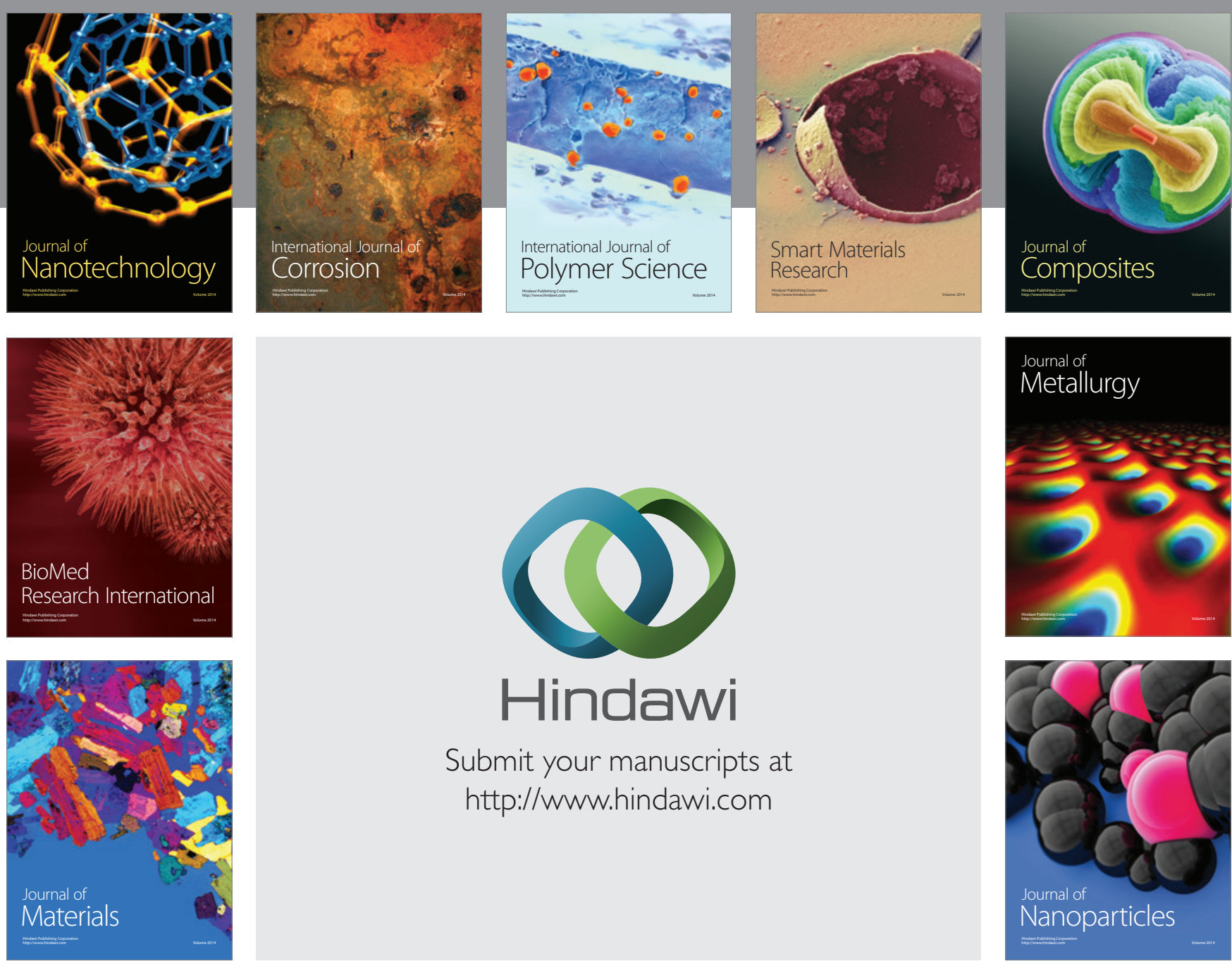

\section{Hindawi}

Submit your manuscripts at

http://www.hindawi.com

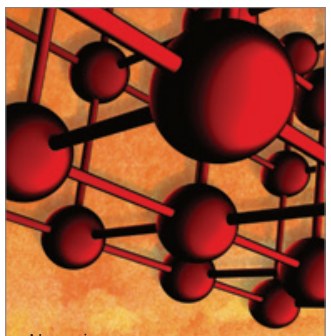

Materials Science and Engineering
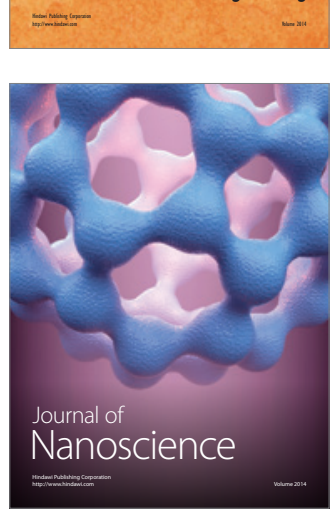
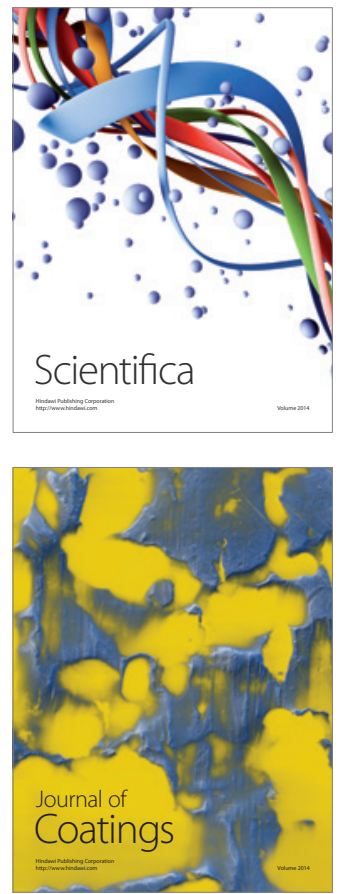
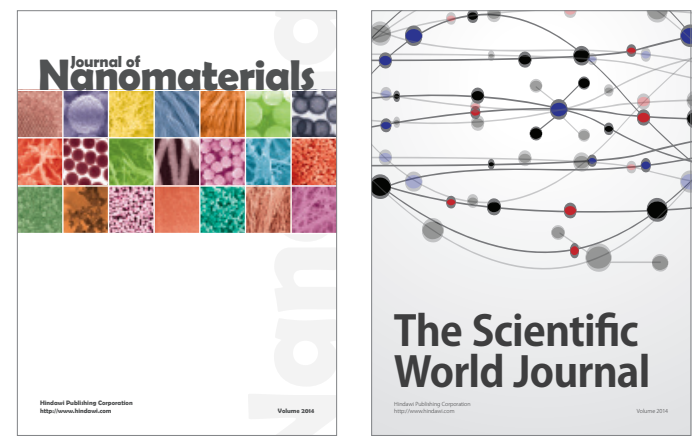

The Scientific World Journal
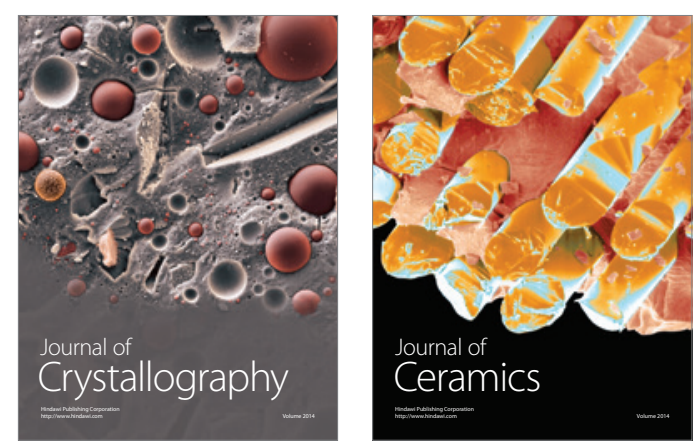
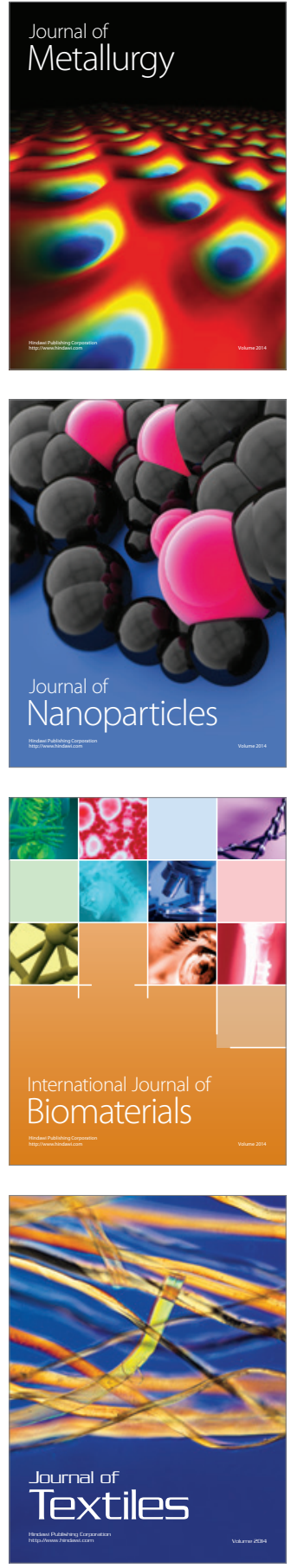